\title{
RESIKO DAN HAZARD DALAM PERENCANAAN ASUHAN KEPERAWATAN
}

\author{
Sri Lailan Nazmi Saragih \\ Email : lailansaragih9@gmail.com
}

\begin{abstract}
ABSTRAK
Kesehatan kerja dirumah sakit mempunyai resiko . Sumber bahaya yang ada di Rumah Sakit harus diidentifikasi dan dinilai untuk menentukan tingkat risiko, yang merupakan tolak ukur kemungkinan terjadinya kecelakaan akibat kerja dan penyakit akibat kerja. Pada hakekatnya Keselamatan dan Kesehatan Kerja (K3) merupakan suatu usaha untuk menciptakan perlindungan dan keamanan dari berbagai risiko kecelakaan dan bahaya, baik fisik, mental maupun emosional terhadap pekerja, perusahaan, masyarakat dan lingkungan. Disamping itu, keselamatan dan kesehatan kerja diharapkan dapat menciptakan kenyamanan kerja dan keselamatan kerja yang tinggi. Setiap tindakan yang dilakukan oleh perawat mempunyai potensi bahaya berupa bahaya fisik, biologi, dan ergonomi. Bahaya fisik didapatkan pada pekerjaan yang menggunakan alat yang tajam, seperti memasang infus dan menjahit luka. untuk mengurangi atau menghilangkan bahaya yang dapat menyebabkan kecelakaan di tempat kerja.
\end{abstract}

\section{Kata Kunci : Kesehatan Kerja, Hazard, Perawat}

\begin{abstract}
Occupational health in hospitals has risks. The source of hazards in the hospital must be identified and assessed to determine the level of risk, which is a measure of the possibility of occupational accidents and occupational diseases. In essence, Occupational Safety and Health (K3) is an effort to create protection and security from various risks of accidents and dangers, both physical, mental and emotional to workers, companies, communities and the environment. In addition, work safety and health are expected to create high work comfort and safety. Every action taken by a nurse has a potential hazard in the form of physical, biological, and ergonomic hazards. Physical hazards are found in jobs that use sharp tools, such as inserting IVs and sewing wounds. to reduce or eliminate hazards that can cause accidents in the workplace.
\end{abstract}

Keywords: Occupational Health, Hazard, Nurse 


\section{LATAR BELAKANG}

Kesadaran terhadap K3 meminimalkan resiko kecelakaan di perusahaan. Di antaranya menurut Hati \& Irawati (2016) bahwa melakukan pekerjaan sesuai dengan standard dan prosedur kerja adalah bagian dari keterampilan kerja, sikap melakukan pekerjaan sesuai prosedur adalah bagian dari sikap professional dalam bekerja. Sesuai dengan penelitian Hati \& Wahyuni (2016) ada kesadaran karyawan dalam mematuhi prosedur untuk meminimalkan resiko kecelakaan di tempat kerja. Maka diperlukan suatu menajemen risiko kegiatannya meliputi identifikasi bahaya, analisis potensi bahaya, penilaian risiko, pengendalian risiko, serta pemantauan dan evaluasi. Menurut Restuputri \& Sari (2015), bahwa untuk mengurangi atau menghilangkan bahaya yang dapat menyebabkan kecelakaan di tempat kerja maka diperlukan suatu manajemen risiko kegiatannya meliputi identifikasi bahaya, analisis potensi bahaya, penilaian risiko, pengendalian risiko, serta pemantauan dan evaluasi. Dalam proses identifikasi dan melakukan analisis potensi bahaya dapat menggunakan metode Hazard and Operability study (HAZOP). HAZOP adalah studi keselamatan yang sistematis, berdasarkan pendekatan sistemik ke arah penilaian keselamatan dan proses pengoperasian peralatan yang kompleks, atau proses produksi (Kotek dalam Restuputri \& Sari, 2015). Tujuannya untuk mengidentifikasi kemungkinan bahaya yang muncul dalam fasilitas pengelolaan di perusahaan menghilangkan sumber utama kecelakaan, seperti rilis beracun, ledakan dan kebakaran (Dunjo dalam Restuputri \& Sari, 2015).

Bahaya potensial keselamatan dan kesehatan kerja bagi tenaga medis khusus hewan yaitu faktor kimia seperti ammonia, karbon monoksida, desinfektan, gas anastesi, hydrogen sulfida dan obat berbahaya lainnya, sedangkan faktor biologi seperti parasit, virus flu babi, rabies, tuberkulosis serta penyakit yang bersumber dari hewan (zoonosis), faktor fisik seperti kebisingan, radiasi pengion, suhu, bahaya laser, debu, lantai licin, jarum suntik, pisau bedah serta benda tajam lainnya, sedangkan untuk faktor ergonomis seperti keseleo, cedera punggung pada saat mengangkat, menahan, dan merawat hewan serta faktor psikososial seperti kerja bergilir, beban kerja, hubungan sesama pekerja/atasan dapat mengakibatkan penyakit dan kecelakaan akibat kerja.

\section{METODE PENELITIAN}

Pengkajian ini menggunakan metode kualitatif yang dilakukan dengan cara mengumpulkan sebanyak-banyaknya data untuk dianalisis, yaitu dengan menggunakan literature view yang berkenaan dengan judul pembahasan yaitu mengenai Resiko dan Hazard dalam Perencanaan Asuhan Keperawatan. Adapun Literature View yang digunakan adalah Buku Teks, Buku Referensi, Jurnal Elektronik, Reasearch, dan hasil skripsi. Dengan kata kunci Peran, Kualitas Pelayanan, dan Keperawatan. Dan Literature View yang digunakan dalam metode ini adalah sebanyak 11 Literature View yang diterbitkan 8 tahun terakhir. 


\section{HASIL}

Dari literature view yang saya baca didapatkan bahwa., resiko hazard dalam asuhan keperawatan itu sangat banyak dan Rumah sakit adalah salah satu tempat kerja yang berbahaya dan perawat adalah petugas kesehatan yang sangat berisiko untuk mengalami gangguan kesehatan akibat dari pekerjaannya.

Perawat merupakan salah satu tenaga medis yang memberikan pelayanan kesehatan. Kesehatan dan keselamatan perawat perlu mendapatkan perhatian lebih dibandingkan komponen pelayanan kesehatan lainnya karena tiap harinya mereka bertemu langsung dengan pasien dan bahaya-bahaya yang ada di rumah sakit. Untuk mengetahui bahaya yang mengancam kesehatan dan keselamatan perawat dilakukan suatu identifikasi. Identifikasi bahaya yang didapatkan dari hasil studi literatur dan studi lapangan dengan wawancara, dikelompokkan menjadi lima kategori yaitu biological hazard, chemical hazard, physical hazard, pshychological hazard dan environmental and mechanical/ biomechanical hazard.

Potensi bahaya dirumah sakit, selain penyakit-penyakit infeksi juga ada potensi bahaya-bahaya lain yang memengaruhi situasi dan kondisi di RS, yaitu kecelakaan (peledakan, kebakaran, kecelakaaan yang berhubungan dengan instalasi listrik, dan sumber-sumber cedera lainya), radiasi, bahan-bahan kimia yang berbahaya, gas-gas anestesi, gangguan psikososial dan ergonomi. Semua potensi bahaya tersebut diatas, jelas mengancam jiwa dan kehidupan bagi para karyawan di RS, para pasien maupun para pengunjung yang ada di lingkungan RS.

Sebuah rumah sakit terpapar pada banyak bahaya di tempat kerja yang dapat menimbulkan bahaya langsung bagi tenaga kerja rumah sakit sehubungan dengan kesehatan dan kesejahteraan mereka, dan ini dapat memiliki konsekuensi yang luas untuk kualitas dan efisiensi perawatan rumah sakit. Program K3 telah menjadi respon organisasi utama untuk mengidentifikasi bahaya ini dan secara proaktif meminimalkan dampaknya terhadap tenaga kerja rumah sakit. Perawat adalah tenaga kesehatan yang paling dominan, dan mereka yang memiliki kontak paling lama dengan pasien, sehingga pekerjaan mereka berpotensi sangat berbahaya. Praktik perawat di lingkungan yang mengandung bahaya biologis, kimia, fisik, dan psikologis. Faktor-faktor ini menempatkan perawat pada risiko kelelahan kerja, stres, penyakit dan cedera terkait pekerjaan, pajanan patogen melalui darah, pajanan penyakit menular, dan gangguan muskuloskeletal. Dengan demikian, pemberi kerja keperawatan dan perawat individu bertanggung jawab untuk meminimalkan atau menghilangkan bahaya ini di tempat kerja sedapat mungkin. Implementasi K3 untuk perawat berfungsi untuk menciptakan layanan kesehatan yang aman tidak hanya untuk pasien, tetapi juga untuk perawat itu sendiri.

Melihat dari berbagai potensi bahaya tersebut maka perlu upaya untuk mengendalikan, meminimalisasi dan bila mungkin meniadakan bahaya yang dapat timbul didalam pelayanan kesehatan. Oleh 
karena itu K3 rumah sakit dapat dikelola dengan baik untuk pelaksanaan di pelayanan kesehatan seperti puskesmas atau klinik yang tujuannya adalah melindungi pasien, pengunjung, pekerja dan masyarakat sekitar ditempat kerja.

\section{PEMBAHASAN}

\section{A. Risiko dan Hazard}

Risiko adalah adalah ukuran kemungkinan kerugian yang timbul dari sumber bahaya (hazard) tertentu yang terjadi, dengan kata lain risiko adalah probabilitas kerusakan atau kerugian dari hazard yang melekat pada spesifik individu atau kelompok yang terpapar oleh hazard tersebut. Risiko merupakan akumulasi dari potensi hazard, konsekuensi yang diakibatkannya, durasi pemaparan dan probabilitas yang ditimbulkannya. Risiko merupakan gambaran kuantitatif dari kemungkinan kerugian yang mempertimbangkan kemungkinan suatu hazard yang akan mengakibatkan suatu peristiwa tersebut (DOE, USA, 1996).

Istilah hazard atau potensi bahaya menunjukan adanya sesuatu yang potensial untuk mengakibatkan cedera atau penyakit, kerusakan atau kerugian yang dapat dialami oleh tenaga kerja atau instansi. Sedang kemungkinan potensi bahaya menjadi manifest, sering disebut resiko. Baik "hazard" maupun "resiko" tidak selamanya menjadi bahaya, asalkan upaya pengendaliannya dilaksanakan dengan baik.

\section{B. Pengendalian Risiko dan Hazard}

Hazard adalah sesuatu yang menimbulkan kerugian, kerugian ini meliputi pada gangguan kesehatan dan cidera, hilangnya waktu kerja, kerusakan pada property, area atau tempat kerja, produk atau lingkungan, kerugian pada proses produksi ataupun kerusakan kerusakan lainnya. Firence (1978) mendefinisikan hazard sebagai suatu material atau kondisi yang berpotensi ditempat kerja dimana dengan atau tanpa interaksi dengan variabel lain dapat menyebabkan kematian, cedera, atau kerugian lain.

Komponen Bahaya :

1. Karakteristik material.

2. Bentuk material.

3. Hubungan pekerjaan dan efek.

4. Kondisi dan frekuensi penggunaan.

5. Tingkah laku pekerja.

Hazard atau bahaya dapat dihindari ataupun dampak dari hazard tersebut dapat diminimalkan. Menurut PERMENAKER No. 05/MEN/1996, pengendalian risiko kecelakaan dan penyakit akibat kerja dilakukan dengan berbagai macam metode, yaitu:

1. Pengendalian teknis atau rekayasa yang meliputi eliminasi, subtitusi, isolasi, ventilasi, higiene, dan sanitasi (engineering control).

2. Pendidikan dan pelatihan.

3. Pembangunan kesadaran dan motivasi yang meliputi sistem bonus, insentif, penghargaan, dan motivasi diri.

4. Evaluasi melalui internal audit, penyelidikan dan etiologi. 
5. Penegakan hukum.

6. Pemberian alat pelindung diri/ APD

Alat Pelindung Diri (APD) adalah pilihan terakhir yang dapat dilakukan untuk mencegah paparan bahaya pada pekerja. Penggunaan APD ini disarankan hanya digunakan bersamaan dengan penggunaan alat pengendali lainnya. Dengan demikian perlindungan keamanan dan kesehatan personel akan lebih efektif.

\section{Upaya Mencegah Dan Meminimalkan Risiko Dan Hazard Pada Tahap Implementasi Asuhan Keperawatan}

Implementasi keperawatan adalah serangkaian kegiatan yang dilakukan oleh perawat untuk membantu klien dari masalah status kesehatan yang dihadapi ke status kesehatan yang lebih baik yang menggambarkan kreteria hasil yang di harapkan (Gordon, 1994, dalam potter dan perry, 1997 )

Tujuan dari pelaksanaan adalah membantu klien mencapai tujuan yang telah ditetapkan, mencakup peningkatan kesehatan, pencegahan, penyakit, pemulihan kesehatan dan memfasilitasi koping.

Contoh upaya mencegah Hazard dan Risiko Implementasi Keperawatan :

1. membantu dalam aktifitas sehari-hari

2. konseling

3. memberikan asuhan keperawatan langsung.

4. Kompensasi untun reaksi yang merugikan.
Teknik tepat dalam memberikan perawatan dan menyiapkan klien utnuk prosedur.

Mencapai tujuan perawatan mengawasi dan menggevaluasi kerja dari anggota staf lain.

Tiga prinsip pedoman implementasi asuhan keperawatan

Mempertahankan keamanan klien

Memberikan asuhan yang efektif

Memberikan asuhan yang seefisien mungkin

\section{KESIMPULAN}

Keselamatan dan Kesehatan Kerja merupakan suatu program didasari pendekatan ilmiah dalam upaya mencegah atau memperkecil terjadinya bahaya (hazard) dan risiko (risk) terjadinya penyakit dan kecelakaan, maupun kerugian-kerugian lainya yang mungkin terjadi. Hazardadalah sesuatu yang menimbulkan kerugian, kerugian ini meliputi pada gangguan kesehatan dan cidera, hilangnya waktu kerja, kerusakan pada property, area atau tempat kerja, produk atau lingkungan, kerugian pada proses produksi ataupun kerusakan - kerusakan lainnya. Berdasarkan karakteristik dampak yang diakibatkan oleh suatu jenis bahaya maka jenis bahaya dapat dikelompokan menjadi 2 yaitu bahaya kesehatan kerja dan bahaya keselamatan kerja

Sedangkan Resiko adalah ukuran kemungkinan kerugian yang timbul dari sumber bahaya (hazard) tertentu yang terjadi. Menurut Kolluru (1996) ada 5 macam tipe risiko, yaitu: risiko 
keselamatan, risiko kesehatan, risiko lingkungan dan ekologi, risiko finansial, danrisiko terhadap masyarakat.

\section{SARAN}

Saat melakukan proses keperawatan, perawat harus benar-benar memperhatikan hazard dan resiko yang kemungkinan terjadi. Hal ini bertujuan untuk mencegah dan menghindari terjadinya kecelakaan kerja, seperti terinfeksi penyakit, mendapatkan kekerasan fisik/verbal saat mengkaji pasien, dan mendapatkan informasi yang tidak sesuai dari pasien. Salah satu cara untuk menghindari dan mencegah terjadinya kecelakaan kerja, maka disarankan untuk menggunakan APD yang sesuai.

\section{DAFTAR PUSTAKA}

Azady, A. A., Widowati, E., \& Rahayu, S. R. (2018). Penggunaan Job Hazard Analysis dalam Identifikasi Risiko Keselamatan Kerja pada Pengrajin Logam. Higeia Journal of Public Health Research and Development, 1(4), 511-513.

Farihah, T. (2016). Manajemen Resiko dan Analisis Hazard Sebagai Dasar Manajemen Keselamatan dan Kesehatan Kerja di UKM Logam (Studi Kasus). Integrated Lab Journal, 4(1), 77-79.

Herawati, Y. T. (2015). Budaya Keselamatan Pasien di Ruang Rawat Inap Rumah Sakit X Kabupaten
Jember. Jurnal IKESMA, 11(1), 5354.

Iftadi, I., Jauhari, W. A., \& Fatmasari, A. (2011). Penentuan Faktor-Faktor Bahaya yang Dihadapi Perawat di RSUD di Kabupaten Karanganyer dan Usaha Pencegahannya Menggunakan Metode AHP. Performa, 10(1), 2-3.

Indragiri, S. (2018). Manajemen Risiko K3 Menggunakan Hazard Identificatiion Risk Assessment And Risk Control (HIRARC). Jurnal Kesehatan, 9(1).

Ivana, A., Widjasena, B., \& Jayanti, S. (2014). Analisa Komitmen Manajemen Rumah Sakit (RS) Terhadap Keselamatan dan Kesehatan Kerja (K3) pada RS Prima Medika Pemalang. Jurnal Kesehatan Masyarakat, 2(1), 36-37.

Pertiwi, Nurhantari, Y., \& Budiharjo, S. (2019). Hazard Identification, risk assessment and risk control serta penerapan risk mapping pada Rumah Sakit Hewan Prof. Soeparwi Universitas Gadjah Mada. Journal of Community Medicine and Public Health, 35(2), 55-58.

Ramdan, I. M., \& Rahman, A. (2017). Analisis Risiko Kesehatan dan Keselamatan Kerja (K3) pada Perawat. JKP, 5(3), 229-231.

Restuputri, D. P., \& Sari, R. P. (2015). Analisis Kecelakaan Kerja dengan Menggunakan Metode Hazard and Operability Study ( HAZOP ). Jurnal Ilmiah Teknik Industri, 14(1), 24-27. 
Simamora, R. H. (n.d.). ROLE CONFLICT

OF NURSE RELATIONSHIP

WITH PERFORMANCE IN The

EMERGENCY UNIT Of Hospitals

RSD DR. SOEBANDI JEMBER.

The Malaysian Journal of Nursing,

3(2), 23-32.

Wijayanti, R., Probandari, A., Aini, M., Salim, A., \& Amalia, H. (2017).

Identifikasi Bahaya , Penilaian

Risiko dan Penentuan Kontrol di

Puskesmas Gambirsari Surakarta.

Indonesian Journal on Medical

Science, 4(2), 150-154. 